\title{
Iberians against locusts: fighting cross-border bio-invaders (1898-1947)
}

\author{
Inês Gomes, ANa Isabel Queiroz and Daniel Alves
}

\section{KEYWORDS: locusts, Iberian Peninsula, historical distribution, con- trol measures.}

JEL CODES: N53, N54, Q00, Q58.

\footnotetext{
$I$ nsects that are potentially harmful to agriculture have shaped agricultural practices and policy-making worldwide. For some species and geographies, historical but also the present and future of pest surges. An overview of Iberian history in relation to the Moroccan locust (Dociostaurus maroccanus) between 1898 and 1947 reveals a) the historical distribution of locust invasions, showing that they were much larger than previously suggested; b) how outbreaks triggered local, regional and national responses, including mandatory regulations, in the last two centuries at least; c) differences and similarities, between countries, and over time, in the control measures applied, which reflect perceptions about the role of authorities and the efficacy of those measures. This paper also adds clarity to the discussion about the factors involved in the decline of outbreaks in recent years and provides a crucial context for future Orthoptera management programmes.
} 


\section{Ibéricos contra gafanhotos: a luta contra bio-invasores transfronteiriços (1898-1947)}

\section{PALAVRAS-CHAVE: gafanhotos, Península Ibérica, distribuição his- tórica, medidas de controle.}

\section{CLASSIFICAÇÃO JEL: N53, N54, Q00, Q58.}

$\int \begin{aligned} & \text { nsetos potencialmente prejudiciais para a agricultura têm moldado as práticas e } \\ & \text { as politicas agrícolas em muitas regiões do planeta. No entanto, a pesquisa his- } \\ & \text { tórica sobre determinadas espécies, em determinados locais, encontra-se ainda por }\end{aligned}$ fazer, não obstante ser crucial, não só para a compreensão do passado, mas também para a compreensão do presente e do futuro das pragas agrícolas. Neste contexto, uma visão global da história ibérica das invasões de gafanhotos (Dociostaurus maroccanus) entre 1898 e 1947 revela a) a distribuição histórica das invasões, mostrando que foi muito maior do que o sugerido anteriormente; b) como os surtos desencadearam respostas locais, regionais e nacionais, incluindo regulamentos para a "extinção dos acrídios", pelo menos, nos últimos dois séculos; c) diferenças e semelhanças nas medidas de controle aplicadas em Portugal e Espanha ao longo do tempo, mostrando a percȩão das populações sobre o papel das autoridades e a eficácia dessas medidas. Este artigo contribui, também, para esclarecer a discussão sobre os fatores que levaram ao declínio dos surtos de gafanhotos nos últimos anos, fornecendo o contexto necessário para estabelecer futuros programas de gestão de ortópteros.

Received: 2017-10-18 - Revised: 2018-04-15 - Accepted: 2018-05-03

Inês Gomes [orcid.org/0000-0001-9210-9959] is a Post-doc Researcher at Centro Interuniversitário de História das Ciências e da Tecnologia (CIUHCT). Address: Departamento de História e Filosofia das Ciências, Faculdade de Ciências da Universidade de Lisboa, Edifício C4, 3. ${ }^{\circ}$ piso, gabinete 09, Campo Grande, 1749-016 Lisboa (Portugal).E-mail:gomes.ida@gmail.com

Ana Isabel Queiroz [orcid.org/0000-0002-0246-2626] is a Fellow Researcher at Institute of Contemporary History (IHC), Faculdade de Ciências Sociais e Humanas, Universidade NOVA de Lisboa. Address: Av. de Berna, 26C, 1069-061_Lisboa (Portugal).E-mail:ai_queiroz@fcsh.unl.pt

Daniel Alves [orcid.org/0000-0002-3541-8197] is Auxiliary Professor at Faculdade de Ciências Sociais e Humanas, Universidade NOVA de Lisboa. Address: Av. de Berna, 26C, 1069-061 Lisboa (Portugal). E-mail:dra@fcsh.unl.pt 
What is the animal that looks like all animals? The locust, because it has the horns of deer, the eyes of cows, the front of horses, the legs of storks, the tail of snakes, and the wings of pigeons (Salido y Estrada, 1874: 69).

\section{INTRODUCTION}

Locust plagues are some of the oldest registered and recurrent insect outbreaks that have forced people to act at various times, in several regions. There is a strong cultural connotation associated with the locust invasions, which are mentioned in a few religious texts (e.g. Kritsky, 1997; Aharoni, 1938; Curtis, 1883). Several studies were recently published on these outbreaks (Sprenger, 2015; Deveson \& Martinez, 2017; Gugliuzzo \& Restifo, 2017; Loskutova \& Fedotova, 2015; Deveson, 2011). Focusing on agricultural losses, studies generally examine distribution, impacts, control measures and perceptions, centering the analysis on a single country, which prevents the exploration of the transnational dynamics regarding how the fight against locusts was carried out ${ }^{1}$. These dynamics seem fundamental since locust surges affect several areas which, in many cases, encompass several countries $^{2}$.

The term "locust" refers to certain species of short-horned grasshoppers in the Acrididae family (Order Orthoptera) that may form a swarm. In a solitary phase, these insects are innocuous to the field crops. However, their transformation from the solitary phase to the gregarious phase results in the long or short-distanced migration-depending on the species- of dense populations and, consequently, agricultural damages. These two phases were first suggested by Boris Uvarov in the 1920s (Uvarov, 1921, 1928). Further research identified intermediate transient phases with morphological and biometric characteristics that distinguish them from other phases and led to the discovery of "permanent zones", continuously occupied habitats where swarms were formed ${ }^{3}$. Although this phenomenon is not completely understood, studies suggest that this transformation occurs under certain propitious climatic conditions and adequate habitat. In the case of the Moroccan locust (Dociostaurus maroccanus) -the species that has been the subject of great concern from the Iberian Peninsula scientific and political authorities- spring rainfall is critical, the optimum being approximately $100 \mathrm{~mm}$. Two or more consecutive years of spring precipitation deficit lead to changes in vegetation cover (creating a characteristic

1. International cooperation between the Soviet authorities and Iran, Afghanistan and Mongolia was, however, analysed by PEYRAT (2014).

2. Cooperation between neighbouring countries is still a major problem (e.g. BELAYNEH, 2005).

3. For a general overview of the phase theory and further research see, for example, WALOFF and Popov (1990). 
mosaic pattern with patches of bare soil and short, tufty grasses) making the habitat very favourable for the species to flourish (Latchininsky, 1998).

Locust swarms have devastated crops and have been a contributory cause of famine, threatening the economy and leading to human migrations. In 1916, the International Institute of Agriculture ${ }^{4}$ published La lutte contre les sauterelles dans les divers pays. This book was an attempt to solv[e] a problem of vital importance to agriculture in several countries: the fight against locusts (International Institute of Agriculture, 1916:V). The urgency of international cooperation in the struggle against these insects was, then, asserted and several international conferences were organised, throughout the twentieth century, to discuss the subject (e.g. Buj, 1996: 165-238; Sistach, 2007: 197-202). Transnational collaboration was, thus, considered fundamental.

The Iberian countries have a track record of locust invasions. Several Spanish studies focused on historical outbreaks, analysing which areas had been infested and what measures had been taken to fight locusts, as well as their effectiveness ${ }^{5}$. Notwithstanding, Spanish historiography forgot the territorial continuity and omitted what was happening in Portugal during the same period. Apart from a brief chronology of locust outbreaks, in Portugal, these plagues have not yet been analysed, neither from an economic, agricultural, and environmental perspective, nor from a historical one (Silva, 1947). A general overview of their geographical impact in both Iberian countries, as well as the measures undertaken to extinguish this insect from the nineteenth century onwards, is still to be made.

A global outlook might be particularly relevant to understand the Iberian history of locust outbreaks, since there are no geographic or ecological boundaries between Portugal and Spain to prevent the movement of animals between them. In fact, these neighbouring countries share the same piece of land, the Iberian Peninsula, surrounded by the Atlantic Ocean on its northern, western and south-western coast, and by the Mediterranean Sea on the south-eastern and eastern coast. Apart from the northern areas, climate is characterised by dry summers and mild, moist winters. Some regions, especially in central Spain, have an extremely low precipitation level and very hot summers, bearing resemblance to desert or semi-arid climates. This continental Mediterranean climate, together with the steppic ecosystems, is particularly suitable for the development of locust outbreaks which, from time to time, rise from the so-called "permanent zones" (un-

4. Its assets were handed over to the Food and Agriculture Organization (FAO) of the United Nations in 1946.

5. For a general overview see, for example, AzCÁRATE (1996: 31-130) and BUJ (1996). 
evenly distributed throughout the Peninsula), invading large areas throughout the Iberian territory (Cañizo, 1942).

Although there are other locusts in the Iberian Peninsula that have occasionally caused agricultural losses, the Moroccan locust, as already mentioned, was the one causing major damages. On a global scale, it is still considered a major pest of many crops due to its voracity and for being a highly polyphagous species, harvesting all main cereals (Latchininsky, 1998).

This paper aims at contributing to a better understanding of locust outbreaks in the Iberian Peninsula. Taking the Portuguese case as a starting point, it provides a comparative historical account of surges and the fight against them in Portugal and Spain. It explores the historical geographical distribution of the Moroccan locust invasions, with emphasis on the outbreaks that occurred between 1898 and 1947. 1898 marks the first Portuguese responses at national level and 1947, the year of the last major outbreak before preventive measures started to be taken in Portugal. There are few records of outbreaks before and after this timespan. Therefore, general aspects of legislative acts and control measures issued before 1898 and until the present time will also be mentioned. Firstly, the historical and geographical distribution of the Moroccan locust invasions will be explored. Secondly, Portuguese and Spanish legislative acts will be analysed, comparing the ways in which both countries addressed the locust outbreaks in terms of logistical and administrative resources. Thirdly, the control measures and other measures that have been taken on the ground, throughout the years, will be described. Lastly, the paper will deal with people's perceptions regarding the locusts' origin and the effectiveness of the measures taken against them.

The following research questions will be addressed: a) What areas were affected by the locust outbreaks?; b) How did those outbreaks change over time?; c) Were the control measures in Portugal and Spain similar?; d) Were Iberians fighting the locusts together, as recommended by international institutions?; e) How was the plague and the action of "neighbours" perceived?

By focusing on the Iberian case, this article ultimately aims to contribute to a broader understanding of the measures implemented worldwide in the fight against a cross-border bio-invader that threatened national and international economies. Moreover, considering that the European Red List of Grasshoppers, Crickets and Bush-crickets has only very recently been published (Hochkirch et al., 2016) and in a context where a clear picture of the dynamics and regulation of the grasshopper populations arises from an increased attention on long term descriptive studies (Chapman \& Joern, 1990: 466), this research 
also has the goal to promote better understanding of change over the years. The main purpose of this analysis is not to analyse the environmental impact of control measures or land use change -issues where IUCN recognised there are knowledge gaps (Hochkirch et al., 2016) - but to identify general trends and patterns of locust outbreaks and procedures to contain them over time. The research intends to stimulate further research which consider historical data, emphasising forgotten aspects of locusts' life histories, contributing, thus, to the discussion about the factors that led to the outbreaks' decline, and providing a more informed context for future Orthoptera management programmes.

\section{SOURCES AND METHODOLOGY}

This paper adopts a comparative approach, trying to find common strategies, collaboration and potential coordination between Iberian countries. Sources report locust outbreaks, their spread and the control measures taken to mitigate impacts. Special attention was given to data reporting the historical geographic distributions of the locust invasions. The information on the occurrences was linked to geographical coordinates in a relational database and analysed in a Geographic Information System.

Texts from Azcárate (1996) and Buj (1996) were crucial in the identification of the geography of the invasions, and the understanding of the main responses to the locust outbreaks throughout time in Spain. Mostly digitalised and freely accessible, the nineteenth and twentieth century reports and agricultural publications also constituted the support for an investigation which was intended to extend to the entire Iberian area.

As far as Portugal is concerned, primary sources were analysed: legislation, official regulations, technical reports and administrative documents, namely the correspondence between local and regional institutions (such as civil governors and municipal authorities) and national agencies of agriculture and plant pathology. Newspaper articles were also an important source, used ad libitum for their useful insight into the popular perceptions of the locust outbreaks ${ }^{6}$. Moreover, newspapers report surges on a local and regional scale, dimensions often not so noticeable in the official documents, allowing us to understand how national policies were applied locally.

Some limitations were considered when drawing spatial references on maps at a national and Iberian scale. Throughout the historical record, a few unevenly distributed sources indicated precise locations which could be translated into latitude-longitude co-

6. See http://www.fcsh.unl.pt/pragasnosperiodicos/ [Late accessed on 13 ${ }^{\text {th }}$ March 2018]. 
ordinates. However, many sources only offered a general impression of the territorial units where locusts were found (e.g. parish, municipality or district). The first were accurately marked through a point on the map whereas the latter were converted from a polygon to a specific location using their centroid. The references to locust invaded areas are sometimes based on second-hand information or inexpert observations, for instance, in local newspapers.

High resolution maps on the historical distribution in Portugal were created based on those detailed primary sources. The Spanish sources already summarised and compiled information, reporting more data on the affected provinces than on localities, and giving greater attention to years of major outbreaks. Thus, to compare the Portuguese and Spanish cases, the analysis was conducted at a regional level, considering the districts (in Portugal) and the provinces (in Spain) as equivalent administrative/territorial units ${ }^{7}$.

A few concepts and limitations should still be clarified. The Moroccan locust goes through the egg, nymph and adult stages. The eggs are laid during summer and remain in the soil until the following spring, when they hatch. New-born nymphs undergo an incomplete metamorphosis, going through intermediate stages until they reach the adult stage, which usually occurs in summer. Adults differ from nymphs in their ability to fly. The Portuguese and Spanish terms equivalent to "outbreaks", "invasions" and "infestation" are used interchangeably, referring to a sudden increase in locust populations due to migration or the hatching of eggs. Some sources did not refer the specific designation of the species that caused the invasion. General terms like "locusts" or "acridians" were frequently used instead of the correspondent scientific name. Although there is a low risk of error since other species were less frequent and only occurred profusely in very specific locations, in some rare cases, other acridians might have been responsible for the invasions, and not the Moroccan locust.

\section{SPATIAL ANALYSIS OF HISTORICAL LOCUST OUTBREAKS}

From the late nineteenth century to the mid-twentieth century there were several locust infestations in the Iberian Peninsula which were considered a serious agricultural problem. Figure 1 illustrates the 824 records of invasions, between 1898 and 1947, mentioned in the sources analysed. Data was organised in different categories according to distribution.

7. The Portuguese districts represented correspond to those delimited in the twentieth century, which were in force between 1926 and 2011. 


\section{FIGURE 1}

Provinces (Spain) and districts (Portugal) affected by locust outbreaks by categories of frequency, 1898-1947

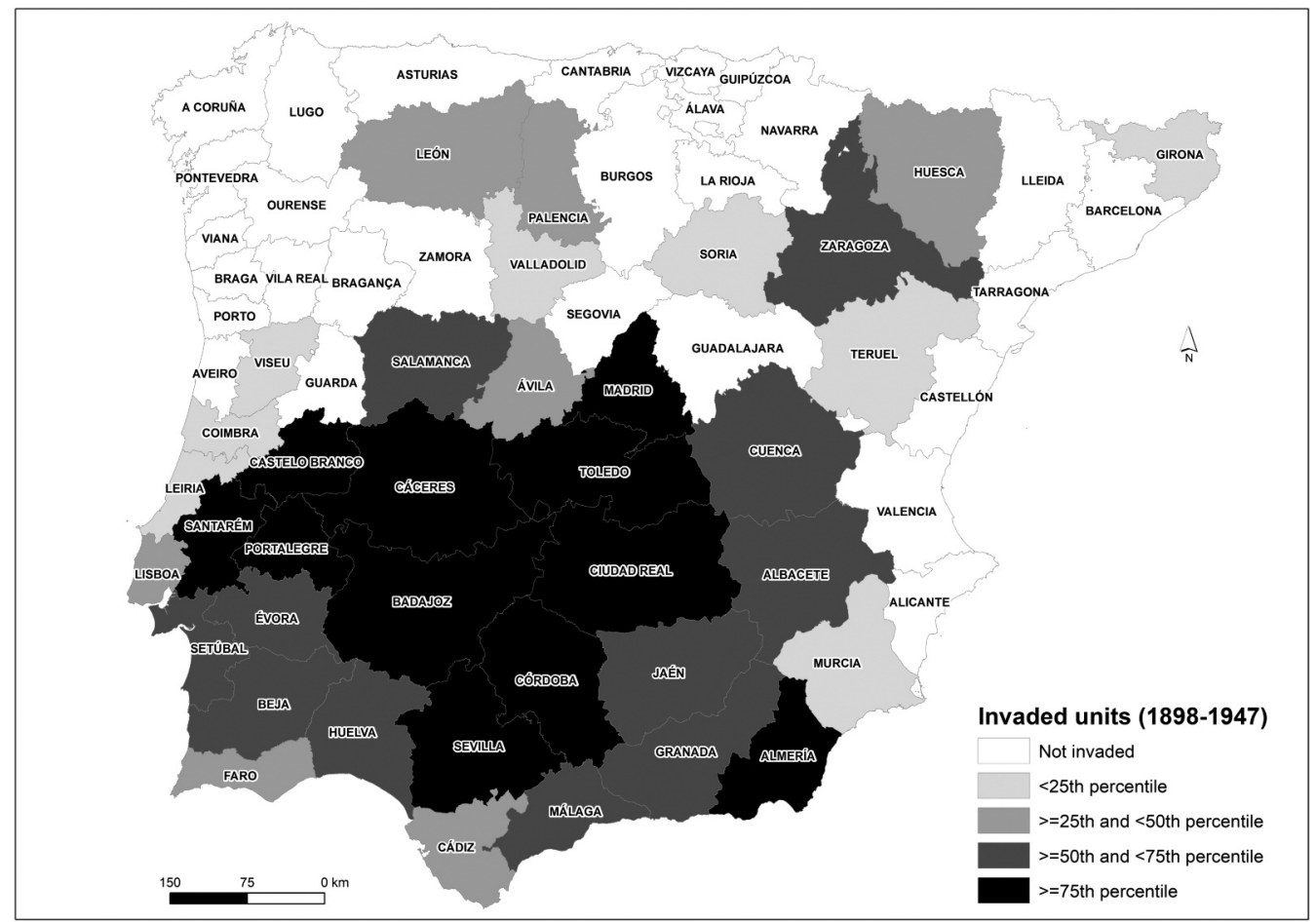

Source: see section 2 for method used for analysing the data here presented.

Figure 1 reveals no historical surges in the north or east of the peninsula or only a few sporadic ones in Spanish provinces. The highest frequency of repeated outbreaks was in the southern and south-western area of the peninsula. Cáceres and Badajoz were the Spanish border provinces with more registered surges from 1898 to 1947 . Their neighbouring Portuguese districts, Castelo Branco and Portalegre were in the same category of frequency.

In the 1940s, a Spanish research about the Moroccan locust and climate identified three different areas in the Iberian Peninsula related to the presence or absence of locusts (Cañizo, 1942). These included areas where locusts were not present; areas where locusts were always present (called "permanent zones" or "reserves") where, under certain climatic conditions, they became gregarious, starting migrations to broader areas; and areas that could potentially be invaded by migrating swarms. Contrary to that study, our data shows a historical invasion area much larger than the one suggested at the time. In the Portuguese area alone, we compiled 671 historical records of locust invasions. Por- 
tugal had a large suitable area for locust outbreaks and invasions. In the 1940s, "permanent zones" were also identified by Portuguese entomologists and engineers ${ }^{8}$.

The detailed data from Portugal allowed for the study of the spatial impact of locust outbreaks per year (Figure 2). Three major surges (MS) stood out: MS1, from 1898 to 1905; MS2, from 1914 to 1922; and MS3, from 1943 to 1947. During other periods, locust outbreaks affected one or two Portuguese districts: 1907 (Santarém and Portalegre); 1908-1910 (Portalegre); 1914 (Santarém); 1924 (Portalegre); 1934-1935 (Portalegre).

FIGURE 2

Number of districts affected by locust outbreaks in Portugal, 1898-1947. Three major surges (MS) are revealed: MS1 (1898-1905); MS2 (1914-1922); MS3 (1943-1947)

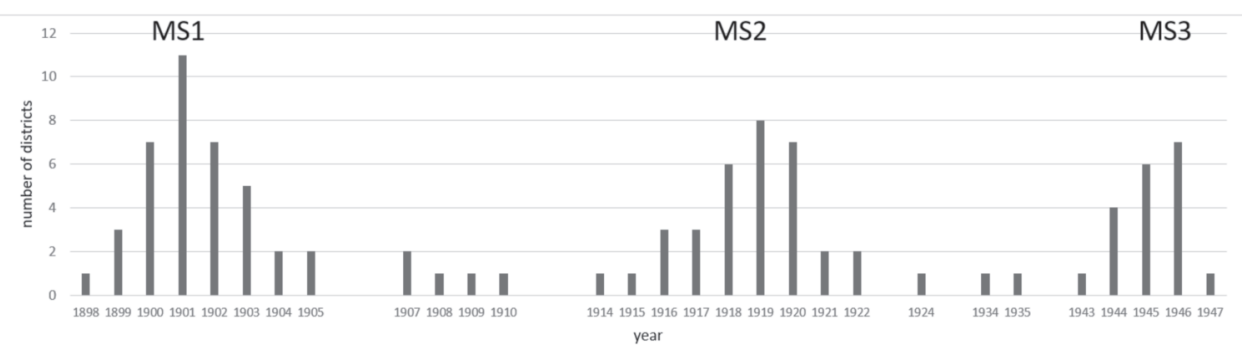

Source: see section 2 for method used for analysing the data here presented.

The graph shows the existence of periods of increasing incidence in each MS period, until a maximum number of affected districts is reached $(\mathrm{MS} 1, \mathrm{nmax}=11 ; \mathrm{MS} 2, \mathrm{nmax}=$ 8 ; MS3, nmax $=7$ ), followed by a decrease. This evidence suggests a self-regulating process. The increase results from a transformation to the gregarious phase, followed by migrations, which could reach hundreds of kilometres ${ }^{9}$. When locusts encounter unsuitable climatic conditions, or unsuitable habitats, they tend to return to their solitary phase, reducing, thereby, the area of invasion ${ }^{10}$. This pattern is similar to the one concerning the

8. CaÑIzo (1942) identified five "permanent zones" in Spain: 1) Trujillo and Llanos de Cáceres (Cáceres); 2) La Serena (Badajoz); 3) Los Pedroches (Córdoba); 4) Valle de Alcudia (Ciudad Real); and 5) Los Monegros (Huesca and Zaragoza). As far as Portugal is concerned, from 1947 onwards, the National Agronomic Station (Estação Agronómica Nacional) prospected the Portuguese "permanent zones" - usually referred as "gregarious foci"- which corresponded to extensive areas located in the most frequently affected districts: Santarém, Setúbal, Portalegre, Castelo Branco, Évora and Beja.

9. If favourable climatic conditions affected broader areas of the Iberian Peninsula, outbreaks might occur, simultaneously, in different "permanent zones" or "reserves".

10. As mentioned in methodology, the data on the Spanish case was not detailed enough so that a comparison of patterns of incidence could be extended to the whole period under study. However, a 
number of neighbouring countries in which the Desert locust (Shistocerca gregaria) outbreaks were reported throughout several years (Chapman \& Joern, 1990: 424-27). It is also like the pattern of other orthopteran outbreaks, when considering the fluctuations in relative abundance over time (Chapman \& Joern, 1990: 424-27).

The Portalegre and Castelo Branco districts have always been subjected to locust infestations, whereas other areas only had outbreaks in a specific period (Figure 3). A brief description of each major surge complements the records of occurrence drawn on the maps.

\subsection{MS1 (1898-1905)}

This well documented surge started in Spain and spread, reaching the south-eastern area of the Faro district. The exact species was not identified in 1898. Occasionally, harmless African locusts invaded this area and some people thought that in 1898 this was the case. However, they were wrong, as these insects were a different species. They had laid eggs on the soil which led to a major outbreak the following spring.

To better understand the dimensions of the 1899's invasion, only in the district of Faro (in the south of Portugal) 1,000 ton of locusts was caught (Monteiro, 1900:2), which is a tremendous number of individual specimens as one kilogram of locusts contained about 14,931 insects (Seabra, 1900: 36). In the same year, 60,000 eggs per square meter were found (Dirección General de Agricultura, Minas y Montes, 1920: 7). Two years later, the numbers were still staggering ${ }^{11}$.

National authorities reacted, adopting measures to contain the surge. Detailed reports with information about the places where the locusts had laid their eggs in every estate were written to destroy them before the following spring. Meticulous maps of the district of Beja were drawn, pinpointing those areas and displaying the route of the insect ${ }^{12}$.

similar pattern was found between 1899 and $1902(\mathrm{n}=11$ in $1899 ; \mathrm{n}=16$ in $1900 ; \mathrm{n}=22$ in 1901 ; $\mathrm{n}=16$ in 1902).

11. Arquivo Nacional Torre do Tombo-Ministério das Obras Públicas, Comércio e Indústria (ANTT-MOPCI), mç. 905, doc. 1. Monteiro, José Anastácio "Relatório do Chefe de Repartição dos Serviços Pecuários dirigido ao Director Geral de Agricultura, sobre Os Serviços de Extinção dos Gafanhotos em 1901", $2^{\text {nd }}$ March 1902. More information on the weight of locusts caught can be found at: http://www.fcsh.unl.pt/pragasnosperiodicos/ [Late accessed on 13th March 2018].

12. ANTT-MOPCI, mç. 957, doc. 18-5. Coelho de Bivar, José de Almeida, "Districto de Beja, Concelhos invadidos pelos gafanhotos, Marcha e superfície de postura em 1899", 30 $0^{\text {th }}$ August 1899. 


\section{FIGURE 3}

\section{Locations of locust outbreaks in Portugal:}

1898-1905 (MS1), 1914-1922 (MS2), and 1943-1947 (MS3)

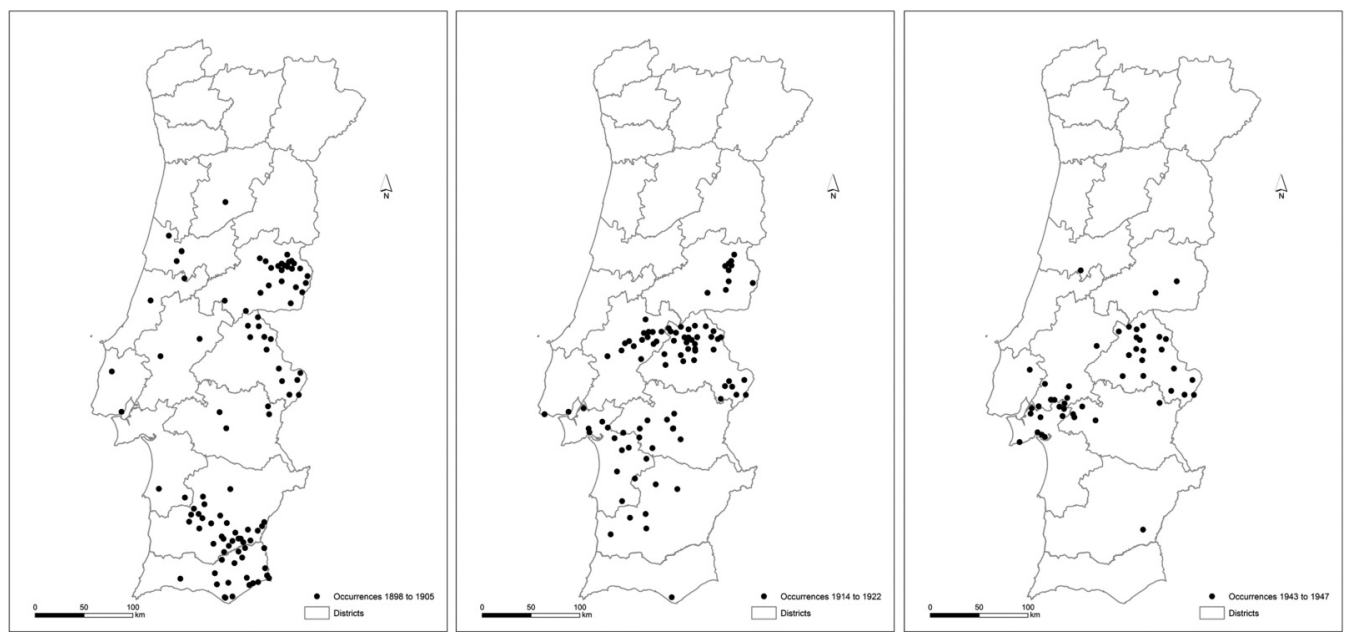

Source: see section 2 for method used for analysing the data here presented.

Despite control measures, the scourge did not diminish, and, in fact, it spread from the south to the north. In 1901, it reached its maximum in terms of number of infested districts (Figure 2). These locusts had different origins: the hatching of eggs deposited by locusts in previous years and the successive invasions coming from neighbouring areas. In fact, various swarms had arrived in the country, through the border, crossing it at multiple points and at various times. For instance, during 1901, locusts entered the district of Castelo Branco, from Spain, at least two times, on June $6^{\text {th }}$ and July $2^{\text {nd }}$. Portalegre was also invaded in late July, when locusts spread throughout the district during the following c. 15 days. Simultaneously, Beja and Faro, which were already, as other districts, fighting locusts born on Portuguese soil, were also struggling with new invasions that were coming from the Spanish territory. As a flying species, it was easy for the locusts to travel to numerous districts, namely Évora, Santarém, Leiria, Coimbra and even Viseu ${ }^{13}$. The situation seemed out of control. A fierce combat continued to be fought in the following years.

By 1905, the locusts seemed to have been defeated, occurring only in Portalegre and Castelo Branco, the most affected Portuguese districts during the entire period studied, which bordered the Spanish province of Extremadura.

13. ANTT-MOPCI, mç. 905, doc. 1. Monteiro, José Anastácio "Relatório do Chefe de Repartição dos Serviços Pecuários dirigido ao Director Geral de Agricultura, sobre Os Serviços de Extinção dos Gafanhotos em 1901”, 2 $2^{\text {nd }}$ March 1902. 


\subsection{MS2 (1914-1922)}

Locusts' first appearance in 1914, in Santarém, seemed to have been controlled. However, their occurrence in 1915 in the northern area of Portalegre was neglected, which probably led to their reappearance in two more districts the following year (Silva, 1947: 31-2). Fortunately, losses were not substantial in 1916, contrary to what happened in 1917, when, although the number of affected districts remained constant, the frightening march of acridians increased the invaded area. Spreading to the neighbouring municipalities still deemed undamaged, threatening the destruction of future crops, this outbreak triggered political decisions about control measures ${ }^{14}$.

By 1918, the huge expansion of the invaded area made it clear that the fight was far from over. Understanding the plague became crucial for its fight. Queries were carried out to find, with exactitude, which places had been invaded, what the specimens' origin was and where the locusts had laid their eggs. Information about their life cycle was considered fundamental: the month in which the eggs had hatched and when the nymphs had passed to the winged state. Control measures were also assessed: what means had been used to extinguish locusts and whether this extinction had been complete or partial; how the workers had been paid (by day or weight); and how the owners, renters or partners, municipal or administrative authorities, military or agricultural associations had helped. Locusts' samples needed to be sent to the central Plant Pathology Laboratory (Laboratório de Patologia Vegetal) to be studied ${ }^{15}$.

Locusts came partly from previously laid out eggs, partly from swarms from various origins and directions, destroying the legend that locusts always follow a fixed direction ${ }^{16}$. In 1919, the surge reached its peak ( $n=8$ districts). Information compiled both in 1918 and 1919 led to the production of hand-made maps by district (Évora, Beja, Lisboa, Santarém, Portalegre and Castelo Branco), which sustained campaigns for locust extinguishment in the following years ${ }^{17}$.

14. Decreto no. 3492 de 25 de outubro de 1917. Diário da República, I Série, no. 185/1917.

15. ANTT-Ministério da Agricultura, $1{ }^{\mathrm{a}}$ incorporação, cx. 446, mç. 1. "Inquéritos sobre a extinção dos acrídios", June-July, 1918.

16. ANTT-Ministério da Agricultura, $1 .^{a}$ incorporação, cx. 446, mç. 1. Vila e Dalmau, Roberto Armando Jerino, "Inquérito sobre a extinção dos acrídios nos concelhos de Niza e Crato", $12^{\text {th }}$ July 1918.

17. See also, ANTT-Ministério da Agricultura, 1. a incorporação, cx. 813, doc. 30. "Inquéritos sobre a extinção dos acrídios”, 1919. 


\subsection{MS3 (1943-1947)}

In the 1940s, at the beginning of the MS3 period, the right bank of the Tagus River (Santarém district) was a fertile region for locust outbreaks. The most intensely infested areas were in Pegões (Setúbal district) and Vendas Novas (Évora district). In the previous twenty years, those areas were dominated by scrublands. The need to increase wheat cultivation led to a significant change in land cover ${ }^{18}$. Landscape became a mosaic of cereals and fallow lands, which created the propitious conditions for the multiplication of locusts and their transition to the gregarious state. The drought of 1943 and 1944 accentuated those conditions. As a result, in 1944, migratory swarms were formed, increasing the area where eggs were laid and leading to a major outbreak in 1945, which became even greater in 1946, since it was only fought in the final stage of locust growth, when the insect was already flying ${ }^{19}$. An intense unprecedented campaign was then prepared. All have fulfilled their duty, even the pest, that died, without [...] causing sensuous harm in the year of $1946^{20}$.

After 1947, occurrences in Portugal were scattered and less frequent. In 1949, three locations from three different districts suffered from surges (Portalegre, Setúbal and Lisboa). In the 1950s, invasions were rarely noticed: one in 1953 in Lisboa district and two in Santarém district, in 1956 and 1957. There were no records of damages after the 1940s.

Meanwhile, locust outbreaks affected a wide area in Spain, particularly in Extremadura, La Mancha and Andalucía, where there were favourable circumstances for their development such as the existence of uncultivated or meadow lands, but also in León, Aragón and Cataluña (Planes, 1949: 175-76). By the end of the twentieth century, locusts were still a concern in southern Spain, particularly in the regions of Extremadura and Andalucía. The need to fight these species was still paramount: the average estimated population of locusts in Extremadura in 1992 was 37,000 per hectare (Arias et al., 1993: 451).

18. The Portuguese State launched a Wheat Campaign, in 1929, to expand the areas for cereal cultivation, increasing production and, thus, contributing to food self-sufficiency (e.g. FREIRE, 2008; PAIS et al., 1976).

19. Gabinete de Planeamento, Políticas e Administração Geral (GPP)-12/68 MABC M-4261. "Memorandum sobre o presente estado do gafanhoto da praga -Dociostaurus Maroccanus Thumb.- em Portugal", September, 1949.

20. GPP-6/264 MABC M-2875. "Relatório da Campanha Anti-Acridiana de 1946”, 1946. 


\section{LEGISLATION REGARDING LOCUSTS}

Outbreaks triggered local, regional and national responses, including mandatory regulations, in both countries, throughout, at least, the last two centuries. This section addresses the historical policies that concerned the fight against locusts in Spain and Portugal. Each law or decree is not fully described but the general trends and patterns in prescriptive measures are identified.

\subsection{Spain}

Spanish rules on how to proceed when locust pests occur exist, at least, since 1390. They have sought to, inter alia, solve the problem of financing control measures (Vázquez Lesmes \& Santiago, 1993: 146). Over the centuries, procedures have been designed, namely in 1755, when, after a major outbreak, an extensive joint action for the whole affected territory was organised and detailed instructions on how to destroy the insect in its diverse growth stages were published (Mas, 2001: 69-72; Azcárate, 1996: 41-7). During the nineteenth and twentieth centuries, these instructions were, generally, accepted and put into practice (Azcárate, 1996: 31-130).

A turning point in Spanish legal framework occurred when the State agricultural engineers became important agents in the pests' control (Buj, 1996: 167-74). Spain approved a detailed law for locust extinction (Ley de Extinción de la Langosta) on $10^{\text {th }}$ January 1879, which stated these engineers were to take part in provincial boards (juntas provinciales), had to confirm the existence of infested areas and inform the Board about the insect's state of development. They also had to be present in every anti-locust campaign (Ministerio de Fomento, 1900). Nevertheless, locals still had to meet their obligations and tasks. Landowners and settlers had to report the presence of locusts if their estates were infested. The municipality, then, ought to inform the civil governor, while it organised a Municipal Council of Extinction (Funta Municipal de Extinción de la Langosta) (Article 1), which, among other things, would demand a list of infested areas from landowners and settlers (Article 7). The civil governor, in turn, would organise a Provincial Board (Funta Provincial de Extinción de la Langosta) and inform the Ministry of Agriculture (Article 3). Furthermore, each landowner should fight the locusts himself or allow others to do so (Article 10). The Board would proceed with the destruction if the landowners refused to do it (Article 10). Inhabitants from the age of 16 to 60 could be requested -with payment- to help the extinction services (Article 15). Budget came from taxes paid to the municipality -to which, taxes from neighbouring towns could also be added (Article 18). Fines were also imposed on landowners or settlers who did not declare infestation on their 
lands or that, in any way, hampered the work of the Board (Articles 25, 26 and 27). This new law marked the strengthening of legislation, bringing the technical-scientific skills of engineers (who then became state employees) to the fight against this pest.

In the years that followed, several other legislative acts introduced administrative changes, i.e. several central and provincial administration bodies responsible for coordination tasks were created while others were extinguished (Dirección General de Agricultura, 1933: 5-15). However, the main guidelines were maintained.

A general law against plant pests, which marked an important milestone in the history of the phytopathology in Spain, was published in 1908. A significant part of this diploma concerned the fight against two major problems: the phylloxera (Articles 18 to 57) and the locusts (Articles 57 to 87). The latter was considered a public calamity so, fighting locusts was a public responsibility ${ }^{21}$. This legal status mirrored the social and economic importance of the locust pests on a national scale. However, despite the new strong wording, the general claims regarding the organisational structure of the fight against the locusts were similar to previous rules: guidelines were defined by the State and the implementation of those guidelines was ensured by regional and local authorities; the landowner or tenant, on his own account, was responsible for the pest's extinction; funds were mainly collected in the municipality; and two extinguish campaigns were to be held each year, one in summer and another in winter. For a long time, this law was Spain's basic legal piece in the fight against locusts (Arias et al., 1993: 428, 449). Although its fundamental essence remained unaltered, on different occasions, some minor legal precepts have been added to this legislation, accommodating scientific and technical developments regarding the fight against agricultural pests, in general, and locust plagues, in particular $^{22}$. Legislative acts that have been continuously published until the present day reveal how the issue remains relevant (Arias et al., 1993: 428-29) ${ }^{23}$.

21. Art. 57, Ley de Extinción de las Plagas del Campo y Defensa contra las mismas, de 21 de mayo de 1908.

22. For an overview of the Spanish regulations see, for example, Dirección GENERAL DE AGRICULTURA (1954: 161-64).

23. See, also Orden de 17 de marzo de 2017 por la que se establecen normas de control integrado contra la langosta mediterranea para la campaña 2017. Diario oficial de Extremadura, no. 59, $27^{\text {th }}$ March 2017. 


\subsection{Portugal}

Until 1899, Portuguese governments reacted to specific plant pests in certain places without any general policy. Specific regulations had been issued, for example in the fight against the Coccus hesperidium in the Azores $(1845 \text { and } 1849)^{24}$, in the fight against the Tortrix viridana $(1893)^{25}$, against the chestnut disease $(1886)^{26}$ and olive tree diseases $(1887)^{27}$. Regarding locusts, since they had caused damages to agriculture on several occasions, rural populations had already been mobilised to kill the insect and take it into the city, as proof that the order had been executed (Silva, 1947: 12-7) ${ }^{28}$. The army was sometimes called to contain the cruel scourge (Silva, 1947: 12-7). In 1873-74 and 1875-76, the House of Representatives (Câmara dos Senhores Deputados) even approved the use of extraordinary funds for the extinction of locusts ${ }^{29}$.

The similarities exhibited by Spanish and Portuguese regulations adopted from 1879 to 1908 in the way services were organised, the responsibilities and the establishment of obligations and sanctions, give us confidence to affirm that acts issued in Spain seem to have inspired the Portuguese legislators. The Decree of $23^{\text {rd }}$ December 1899 is the first general regulation against plant pests in Portugal ${ }^{30}$.Vineyard pests and diseases, particularly phylloxera, had been, until then, a main concern. However, other crops also suffered damages. It was necessary to be watchful, to fend off diseases on their first assault before they could destroy crops. The Government should be able to establish, in the critical moment, the providences which, according to the nature of the incipient evil, [were] more adequate and effective ${ }^{31}$. The Plant Pathology Laboratory, created by this legal text, was the official body for the study of plant disease and plant parasites, and the establishment of measures for the defence and treatment of crops (Article 15). The control measures, however, should be implemented by multiple agents: landowners, beneficial landowners, tenants, overseers, and beneficial holders, as well as associations (e.g. agricultural unions) and local and regional authorities who managed land (Articles 9 to 14). Accordingly, in-

24. Lei de 13 de fevereiro de 1845. Diário do Governo, no. 41/1845; Lei de 14 julho de 1849. Diário do Governo, no. 164/1849.

25. Circular do Diretor Geral de Agricultura de 17 de maio de 1893. Diário do Governo, no. $111 / 1893$.

26. Portaria de 8 de setembro de 1886. Diário do Governo, no. 203/1886

27. Portaria de 10 de novembro de 1887. Diário do Governo, no. 254/1887.

28. There are records of help from the populations, for example, in 1746, 1756, c. 1816 and 1876.

29. Diário da Câmara dos Senhores Deputados, sessão no. 50 de 17 de Março de 1877 e sessão no. 55 de 24 de março de 1877.

30. Preamble, Decreto de 23 de dezembro de 1899. Diário do Governo, no. 292/1899.

31. Id. 
structions on the methods and timing suitable for the application of the measures were provided in an official announcement (Articles 4 and 7), and landowners were obliged to apply control measures or allow access to their lands (Articles 4 and 5). Penalties for non-compliance were laid out (Articles 6, 7, 8 and 28) and the State could replace the addressees if they did not comply with the obligations (Article 6). In addition, fungicides, insecticides and their raw materials - whose trade and distribution were also regulatedwere exempt from import duties, if considered useful and necessary for the development of national agriculture (Article 17).

The 1899 Portuguese decree on agricultural pests resembled the 1879 Spanish law on locusts, although it was a set of generic provisions which could be applied to any plant disease. In other words, the 1899 law was not designed specifically to fight locusts. Detailed measures and regulations, concerning specific pests, were to be published afterwards. Instructions indicating the practical means of fighting locusts were, in fact, issued in May 1900 (Monteiro, 1900). The cursed ones $^{32}$ gave no truce in the years that followed, which justified moving forward to streamline fighting procedures. A regulation (Regulamento dos serviços de extinção dos acrídios) was adopted in $1902^{33}$. Tasks were assigned to official bodies that shared the responsibility with all inhabitants from 18 to 50 years of age, Portuguese or foreign, who live[d] in the [affected] municipalities (Article 1). Killing locusts was, from then on, mandatory (Article 2), and the fight should start immediately after the first invasion, using animals and instruments at their disposal according to instructions that ought to be provided by the Agricultural Services or according to the well known traditional methods (Article 4). Landowners of non-invaded -but neighbouring-properties could be called upon to contribute with personnel to assist services (Article 3). A system of fines was also established for offenders (Articles 6 to 11, 15 and 17 to 20). Landowners were to notify the councillor of their respective parish as soon as swarms were detected. Then the councillor was to communicate the infestation to the municipal administrator, so that the civil governor was informed. He then notified the district's agronomist, who was responsible for establishing the necessary measures (Articles 20 to 23).

The fact that the whole community was involved seems, at first sight, a positive aspect. However, a framework like that implied a complex chain of information and action between multiple agents, which could increase the risk of failure. In fact, the populations complained: despite the numerous technicians responsible for the locusts'

32. As they were called in a local newspaper (Anonymous, 1902b: 1). In portuguese, os malditos.

33. Repartição dos Serviços Agronómicos-Direcção Geral de Agricultura, Regulamento dos Serviços de Extinção dos Acridios aprovado por decreto de 20 de Fevereiro de 1902, Lisboa, Imprensa Nacional, 1903. 
extinction, they were not aware of the death of a single locust due to their job (Anonymous, 1899).

The 1902 Regulation was not repealed in the following decades, despite the various administrative reforms that took place over the years ${ }^{34}$. In 1949, agricultural engineers from the National Agronomic Station (Estação Agronómica Nacional) considered it outdated: no one care[d] to enforce or make others enforce it; and in the face of the biological knowledge about locusts most of the provisions ha[d] no reason to be applied ${ }^{35}$. From the 1940s onwards, the new Portuguese legislation did not ever mention locust outbreaks, events that seemed to have been forgotten, contrary to what had happened on the other side of the border ${ }^{36}$.

\section{FIGHTING THE LOCUSTS}

Fighting locusts in Spain and Portugal was a long and continuous process, which was relatively well documented throughout time. Since the fight was similar in both countries, the analysis of how legal procedures were implemented will be discussed jointly.

Two major periods were distinguished according to the different types of strategy used: 1) the reactive strategy (before the 1940s), which consisted of collective campaigns for the destruction of insects and their postures; and 2) the preventive strategy (after 1940s), which consisted in avoiding the plague's occurrence.

\subsection{Reactive measures (until 1940s)}

The way reactive measures were applied remained unchanged for almost two centuries in Spain (after 1755) and Portugal (after 1900). Measures can be divided according to the time of year in which they were employed -winter or spring. Differences were essentially due to the different stages of development of the insect which required different strategies of destruction. A thorough knowledge of the locusts' life cycle was, in fact,

34. For an overview of the Portuguese laws concerning the fight against the locusts, see SILVA (1947: 38-47).

35. GPP-12/68 MABC M-4261. "Memorandum sobre o presente estado do gafanhoto da praga Dociostaurus Maroccanus Thumb.- em Portugal”, September, 1949.

36. In 1944 (during the last major surge), an ordinance made the fight against acridians mandatory in the municipalities most affected by the plague: Portaria no. 10672 de 27 de Maio de 1944. Diário do Govêrno, I série, no. 113/1944. 
at the base of the adopted measures, which were adapted to the insect's diverse growth stages.

After the first swarms caused distress on the invaded areas during spring and summer, eggs laid on the ground became a major concern. The most convenient seasons for their destruction were autumn and winter: the work of one man, then, match[ed] the work of thirty men, afterwards ${ }^{37}$. At this stage different methods should be used: 1) ploughing or harrowing lands where locust eggs had been laid; 2) feeding pigs on infested grounds; and 3) using hoes or any other instruments to dig the earth and then removing the eggs by hand. Regardless of the methods used, ditches should be dug to bury the eggs ${ }^{38}$.

The winter methods were still considered important in Portugal in 1919 (Ministério da Agricultura, 1919). In Spain, they were even mandatory to farmers who wanted governmental aid. In 1934, for instance, the Agricultural Ministry provided insecticides for spring anti-locust campaigns only to those who had properly run the recommended winter measures (Dirección General de Agricultura, 1935: 173). Spanish agronomic services still considered them crucial when a monitoring service was under preparation in the $1940 \mathrm{~s}$ (Dirección General de Agricultura, 1954: 104). Thereafter, egg destruction campaigns decreased over time as the methods to kill adults became more effective and the preventive measures were introduced (Arias et al., 1993: 426).

Spring campaigns were to start as soon as the nymphs hatched. At this stage, any livestock would be helpful in the destruction of the new-borns through trampling. Workers were used to crush insects on the ground, forming a circle that takes all the stain or the possible part of it, which would narrow and bramble to the centre, where they would beat and whip them with the instruments they carry, as well as squeeze it, burn it or bury it, so that it would not revive (Azcárate, 1996: 44) ${ }^{39}$. They wore leather or hemp soles, beat the floor with mallets and caught insects with nets. Locusts were also picked up by hand ${ }^{40}$.

Similar measures were used to kill adult specimens, although they were less efficient when the locusts reached this developmental stage because they could fly, however, they could still work if applied at dawn, when the insects were less active. Nets, traps or phys-

37. Instrucciones dictadas por el Consejo de Castilla con fecha de 8 de junio de 1755 in AzCÁRATE (1996: 42-46).

38. Id. See also MonTEIRo (1900).

39. See also illustrations of the instruments used (SALIDO y ESTRADA, 1874: 387-407).

40. Instrucciones dictadas por el Consejo de Castilla con fecha de 8 de junio de 1755, in AzCÁRATE (1996: 42-46). See also MonTEIRO (1900). 
ical barriers could also be used to direct the locusts' flight into trenches, where they could be destroyed. Wild and domestic birds, like turkeys and chickens, were considered as important as pigs in the destruction of the adult locust ${ }^{41}$.

Mechanical methods, like the ones depicted, were broadly used until the mid-twentieth century (e.g. Dirección General de Agricultura, 1933) ${ }^{42}$, although they only slightly restrained the spread and somewhat lessened the damage at the expense of important sums (Pestana, 1901: 4). In spite of the general mobilisation in the invaded areas and the destruction of immense amounts of these insects their absence on the fields was not noticeable [...] seeming to everyone that the human forces [were] not enough to extinguish them, and that their devouring craving was such that they even fell on the dead and devoured them (Anonymous, 1756) ${ }^{43}$.

Mechanical methods were maintained through several centuries. Chemical ones, on the other hand, kept being changed from the late nineteenth century, according to the latest research, which intended to develop industrial insecticides safer for humans and domestic animals, as well as easier to apply, more effective, selective and less expensive. Gasoline, soap emulsion and oil, soap and carbon sulphide, creolin, arsenate compounds, fluosilicates, organochlorides or organophosphates, were routinely used, being dispersed with the help of sprays and baits (Buj, 1996; Dirección General de Agricultura, 1954: 69, 98-104) ${ }^{44}$. Industrial insecticides are now recognised as a threat to people's health and biodiversity.

\subsection{Preventive measures (after 1940s)}

The fight against the locusts, not only in the Iberian Peninsula but all over the world, underwent profound changes after the emergence of Boris Uvarov's research about locust

41. Id.

42. See, for example, GPP-6/264 MABC M-2875. Murteira Corado, José da Silva, "Os acrídios na região de Elvas", 1942.

43. Cited in SiLva (1947: 14).

44. See also, for example, ANTT-Ministério da Agricultura, 1. i incorporação, cx. 446, mç. 1. "Inquéritos sobre a extinção dos acrídios", June-July, 1918; ANTT-Ministério da Agricultura, 1. a incorporação, cx. 813, doc. 30. "Inquéritos sobre a extinção dos acrídios", 1919; ANTT-Ministério da Agricultura, 1. incorporação, cx. 813, mç. 30. Câmara Pestana, João da, "Mapas indicativos dos concelhos, freguesias e locais de invasão e postura de gafanhotos em diversos distritos", 1919; GPP12/68 MABC M-4261. "Memorandum sobre o presente estado do gafanhoto da praga -Dociostaurus Maroccanus Thumb.- em Portugal”, September, 1949. For a general overview of the insecticides used in Spain, see ARIAS et al. (1993: 426-27). 
ecology in the $1920 \mathrm{~s}^{45}$. If locusts could be killed in their permanent habitats, the spread of pests to broader areas could be avoided. A new era could, thus, begin: an "era of prevention", based on two distinct stages: 1) prospection; and, if necessary, 2) elimination ${ }^{46}$.

In 1946, a Portuguese entomologist described Uvarov's research and subsequent investigations in detail (Silva, 1946) ${ }^{47}$. His paper was the starting point for the devising of spring preventive campaigns that lasted, at least, until the early 1980s: careful and repeated measurements would, every year, give an idea of the phase which the Moroccan locust was in, as well as the differences to the previous year. This could easily point the optimal opportunity for a small-scale action that would cut off a trend which revealed a dangerous transformation to the gregarious phase (Silva, 1946: 363). Biometric indexing allowed for the recognition of the locust phases; i.e. the solitary, the gregarious and the transient phases have distinct dimensions. The identification enabled the implementation of control measures that would restrain the development of the insect to a complete gregarious phase, with all the negative consequences which that entailed, ensuring the impossibility of large-scale outbreaks ${ }^{48}$.

From 1947 onwards, a permanent monitoring service was established. It contrasted with the structures that had been in place since the end of the nineteenth century to control locust outbreaks. In the following years, entomologists from the National Agronomic Station (Estação Agronómica Nacional) travelled through Portugal prospecting for areas potentially suitable for the development of locust populations into the gregarious phase. Specimens were then collected and measured; indexes were calculated and compared ${ }^{49}$.

\section{See note 3 .}

46. Besides prospection campaigns, the study of the locusts' ecology was considered a crucial issue. Spain and Portugal conducted researches to try to clarify which factors influenced the outbreaks. This research decreased as the pest became less threatening. In particular, the discovery and massive use of chlorate insecticides from 1950 onwards interrupted the Spanish research on the biological mechanisms which transform solitary grasshoppers in gregarious locusts. In this respect see, for example, Moral (1986: 223-31); GPP-6/91 MABC M-2686. Azevedo, Augusto Rosa de \& Silva, Gabriel de Magalhães, "Relatório dos trabalhos de prospecção do gafanhoto marroquino em Portugal", $20^{\text {th }}$ March 1950; GPP-14/88 MABC M-4818. Azevedo, Augusto Rosa de \& Silva, Gabriel de Magalhães, "Relatório dos trabalhos de prospecção do gafanhoto marroquino em Portugal", April, 1954; DIRECCIÓN GENERAL de Agricultura (1954: 51-127); Arias et al. (1993: 427).

47. In Spain, a similar paper was written (CAÑIZO \& MORENO, 1940).

48. GPP-6/305 MABC M-2916. Azevedo, Augusto Rosa de \& Silva, Gabriel de Magalhães, "Relatório dos trabalhos de prospecção do gafanhoto marroquino em Portugal”, February, 1953.

49. GPP-6/91 MABC M-2686. Azevedo, Augusto Rosa de \& Silva, Gabriel de Magalhães, "Relatório dos trabalhos de prospecção do gafanhoto marroquino em Portugal", $20^{\text {th }}$ March 1950; GPP6/305 MABC M-2916. Azevedo, Augusto Rosa de \& Silva, Gabriel de Magalhães, "Relatório dos trabalhos de prospecção do gafanhoto marroquino em Portugal”, February, 1953; GPP-6/90 MABC 
Monitoring became a routine work that effectively allowed for the recognition of populations that could cause agricultural damages in the subsequent years ${ }^{50}$. In these cases, insecticides were used to contain the increase of insects. In 1957, the Moroccan locust was considered a chronic evil that could only be fought with a continuous monitoring service $^{51}$. These preventive measures, which were still being implemented in the early $1980 \mathrm{~s}^{52}$, might have been crucial in the control of the Moroccan locust surges in Portugal. Other factors, such as land cover change and the use of strong insecticides, may also have contributed for decreasing their frequency. A 2009 research about the Portuguese saltopteran fauna did not find the Moroccan locust (Schmidt, Martinho \& Paiva, 2009), although its occurrence was confirmed years after (Pina et al., 2017). Regardless of their presence or absence in fields and natural habitats, entomologists do not seem to remember how locusts were once an agricultural pest (Serafim, 2017).

In Spain, favourable climatic conditions in the late 1930s, associated with the fact that estates had ceased to be cultivated because of the civil war, led to an extended outbreak, giving rise to several legislative acts. A massive campaign to fight the locusts was developed in 1939, while a series of investigations were initiated with the objective of preventing future outbreaks (Arias et al., 1993: 427, 449; Dirección General de Agricultura, 1954: $98)^{53}$. In this context, a permanent defence service with exclusive and specialised personnel was organised in order to identify outbreak areas and contain migrations as the gregarious phase was beginning (Dirección General de Agricultura, 1947: 173) ${ }^{54}$. Antilocust campaigns' organisation, direction and execution, as defined in 1939, were, broadly speaking, similar to how they are today (Arias et al., 1993: 427, 449). Government make insecticides available to landowners, free of charge, that should start to be applied when the locusts are first seen and until they reach the adult state; at the same time, regular visits by technicians to the infested estates allow for the detection of infestations that persist the procedures taken by the landowners and the consequent introduction of additional

M-2685. Azevedo, Augusto Rosa de \& Silva, Gabriel de Magalhães, "Relatório dos trabalhos de prospecção do gafanhoto marroquino em Portugal”, April, 1950; GPP-1/190 MABC M-8926. Azevedo, Augusto Rosa de, "Relatório dos trabalhos de prospecção do gafanhoto marroquino em Portugal em 1956”, March, 1957.

50. GPP-6/90 MABC M-2685. Azevedo, Augusto Rosa de \& Silva, Gabriel de Magalhães, "Relatório dos trabalhos de prospecção do gafanhoto marroquino em Portugal", April, 1950.

51. GPP-1/190 MABC M-8926. Azevedo, Augusto Rosa de, "Relatório dos trabalhos de prospecção do gafanhoto marroquino em Portugal em 1956", March, 1957.

52. Personal notes of J. Monteiro Guimarães describing the 1979, 1980 and 1983 prospecting missions, as well as some measurements and indices for analysing the gregarious tendency. Courtesy Rita Teixeira, Instituto Nacional de Investigação Agrária e Veterinária, IP.

53. Moral (1986) summarizes Spanish research in this area.

54. Cited in Buj (1996: 309). 
measures, namely aerial applications (Arias et al., 1993: 429-31) ${ }^{55}$. These new vigilance policies, as well as the increase of cereals in cultivated areas and the introduction of new insect control insecticides, changed the Moroccan locust status (Buj, 1996: 310). This decline in the severity of the attacks was linked, in the 1950s and 1960s, to the massive use of the $\mathrm{HCH} 25 \%$ insecticide and from the late 1960 s onwards, to the use of aerial insecticide applications (Arias et al., 1993: 427) ${ }^{56}$. No major outbreaks have been recently recorded in Spain. Agronomical services believe locusts will not have the character of public calamity again, being relegated -like any other [potentially] harmful species- to the category of latent plague; duly monitored they ceased to be a nightmare for national agriculture (Dirección General de Agricultura, 1954: 104).

\section{THE NEIGHBOURS' FAULT: THE INGLORIOUS STRUGGLE}

In the 1870s, a swarm left Valle de Alcudia (Ciudad Real), one of the "permanent zones" in Spain, and flew to the neighbouring areas, bringing desolation and ruin. Populations have not ceased to work to contain the evil, avoiding being plunged in the greatest misery (Rivas, 1888: 43). For this reason, the publication of the Ley de Extinción de la Langosta in 1879 was praised.

Despite the high expectations raised by this new law, it was poorly implemented, being almost forgotten; there were no means to apply it. Extinguishing the locusts required that local authorities and landholders coordinated actions and made their own resources available to everyone (Rivas, 1888: 43-4). While farmers who had lost their crops accepted the application of control methods on their fields, the cattle breeders dissented from the established rules (Rivas, 1888: 47). Egg destruction during the winter implied the destruction of pastures. Thus, many dehesa landowners concealed the magnitude of the invasion to avoid expenses and losses (Rivas, 1888: 45). They remained silent as the dead (Rámon y Vidal, 1902: 11) ${ }^{57}$ and, as such, the public control measures were not efficient. This situation has even led to popular riots against landowners who refuse to extinguish the locusts (Anonymous, 1900).

Inaction happened with the connivance of the local boards (juntas locales). Political struggles and local rivalries limited the appliance of the law: some dehesas have been "cleared" without consulting the owners, and in others, [...] no one dared to denounce it.

55. See also orden de 17 de marzo de 2017.

56. See also Pesticide Referee Group (2014).

57. Cited in BuJ (1996: 211). 
Local boards, although in charge of extinguishing the plague, seemed committed to religiously guard that seedbed of insects (Rivas, 1888: 51-2).

The situation remained problematic in 1900: farmers' compensations were unbearable; pasture owners continued to oppose land cleansing; local authorities were still not doing an effective winter campaign; the deficient distribution of gasoline -necessary for the effective employment of the control measures- led to an unequal fight in different places (Ministerio de Agricultura, Industria, Comercio y Obras Públicas, 1902: 59$60)^{58}$.

While the Spanish blamed each other for losses in their own businesses, Portuguese rural populations, local authorities and technical experts blamed the inaction of their Spanish neighbours as they observed locust swarms frequently travelling across the border.

For instance, it was common knowledge that the 1898-1905 surge had started in Spain $^{59}$. For the Portuguese agronomists there was no doubt about this. Locusts in a late growth stage kept flying in from Spain, which prevented the effectiveness of the measures taken by the Portuguese.

While it is true that many of the locust plagues had their origins in Spain, particularly because both the climatic and habitat conditions were more suitable there, the Portuguese perception of the Spanish control actions did not reflect the efforts carried out in the neighbouring country, despite a certain ineffectiveness. The Portuguese ignored the treated area across the border, commented that the subject was walking around [...] neglected (Anonymous, 1903) and lamented the fact that given the abandonment they were also victims (Anonymous, 1902a). In face of the numbness of [his] neighbours (Anonymous, 1902b), the affected populations thought the evil devourers of Spain marched in pursuit of [their] cultures. (Anonymous, 1902a) Such narratives could have been used to back up claims for financial support or to justify the unsuccessful anti-locust campaigns, which, as we have seen, only achieved their goals after the 1940s, although, with an impact on other insects and on the biodiversity in general.

58. Buj described the efforts taken to control the locust outbreaks in the following years. The situation remained the same. The fight between farmers and cattle breeders was regarded as one of the main reasons for the unsuccessfulness of the campaigns (BUJ, 1996: 270). See also MINISTERIO DE FOMENTO (1923: 167).

59. ANTT-MOPCI, mç. 905, doc. 154. Monteiro, José Anastácio, "Relatório do Chefe da Repartição dos Serviços Pecuários dirigido ao Ministro e Secretário de Estado dos Negócios das Obras Públicas, Comércio e Indústria”, December, 1899. 
A widespread opinion, both in newspapers and in the reports of technicians, throughout the twentieth century, was that Iberians should fight the locusts together. However, cooperation and coordination were rare or non-existent. One single record revealed some shared efforts between central authorities. In 1900, Portugal sent a fungus to Spain that was expected to kill locusts, the Empusa acridii ${ }^{60}$. Portugal had received that fungus from the Institute of Grahamstown in Cape Colony (Pestana, 1901) ${ }^{61}$ and, taking into account that the majority of the Portuguese invasions had come from the neighbouring country, the Portuguese government offered some samples to $\operatorname{Spain}^{62}$ : $[\mathrm{t}]$ here is no one who did not see favourably the Iberian union in that sense (Mastbaum, 1901: 117).

The fungus cultures were sent to Madrid, but an Iberian union for this cause remained only a shared desire among Portuguese technicians and populations, during the following decades. Locust reinvasions from Spain continued to be mentioned, rendering the combat efforts almost useless (Ministerio de Agricultura, Industria, Comercio y Obras Públicas, 1901: 82) ${ }^{63}$. Even in 1949, when the scourge was already controlled in Portugal, an understanding between the two countries, although crucial, was still missing ${ }^{64}$.

\section{FINAL REMARKS: A DANGEROUS PATH}

Insects are potentially harmful to agriculture and can lead to famines and economic losses. These threats were, in several occasions, enough to shape agricultural practices and policy-making worldwide. In a context where locust plagues in Portugal have been forgotten, historical research gives us a clear picture of Orthoptera fauna and their evolution in the Iberian Peninsula.

60. At the end of the nineteenth century, locusts were threating agriculture all over the planet. Picking up locusts by hand did not seem like a viable solution. Biological control (i.e. the use of a biological agent to combat a pest, be it a predator or a pathogen) was taking its first steps. In particular, the Institute of Grahamstown in Cape Colony cultivated a fungus (Empusa acridii) that was able to destroy locusts. This fungus was used worldwide, constituting an interesting case of an international scientific cooperation in plant pathology in the turn of the nineteenth century. See MASTBAUM (1900: 259-61).

61. ANTT-MOPCI, mç. 905, doc. 1. Monteiro, José Anastácio "Relatório do Chefe de Repartição dos Serviços Pecuários dirigido ao Director Geral de Agricultura, sobre Os Serviços de Extinção dos Gafanhotos em 1901", 2 $2^{\text {nd }}$ March 1902.

62. ANTT-MOPCI, liv. 715: Livro de Entrada de Ofícios de 20 Abril 1899 a 2 de Junho de 1903. Director Geral de Agricultura de Madrid, "Ofício agradecendo a oferta dos tubos de Empusa acridii e dizendo que aceita a oferta", 24 ${ }^{\text {th }}$ April 1901.

63. See also GPP-6/264 MABC M-2875. "Relatório da Campanha Anti-Acridiana de 1946”, 1946.

64. GPP-12/68 MABC M-4261. "Memorandum sobre o presente estado do gafanhoto da praga Dociostaurus Maroccanus Thumb.- em Portugal”, September, 1949. 
A thorough knowledge of legislative acts approved until the mid-twentieth century, allows an assessment of the continuous interest in locust control, both in Portugal and Spain. Overall, governments deal with plant pests in two different ways: 1) approving legal measures to prevent the infestation, including protectionist measures which restrict the entry and circulation of certain products; or 2) approving control programmes which intend to extinguish the pest or at least contain its development. As far as locusts are concerned, this latter mechanism was crucial. As in other countries, the Portuguese and Spanish governments took a leading role in structuring the fight against this evil. However, if the influence of centralised directives was undeniable, the process of implementing the measures also meant an organisational effort driven by regional or local authorities and populations that, to kill the insect, ought to organise a well-structured scheme where everyone had a role to play.

The 1879 Spanish law and its counterpart, the 1902 Portuguese law, were the culmination of a continuous process that for several centuries was trying to regulate the fight against locusts. Until the mid-twentieth century reactive measures were approved; afterwards preventive measures took the lead. From the late 1940s onward, Portugal and Spain, focused their attention on "permanent zones". However, the ways in which each country fought the Moroccan locust seem to have been quite different. Portugal paid attention to the transient phases, preventing the locusts from reaching the gregarious phase; Spain -maybe due to the larger areas that had to be prospected- based its action on earlywarnings of gregarious stages, preventing swarm formation and subsequent damage to crops. Although it is hard to access with precision the real impact of locusts on agriculture, the perception of its impact has always been dramatic. Fear, even if not justified, seemed to have influenced and legitimised the adoption of public control measures. The legislative acts might not reflect the negative impact locusts had on the Spanish and Portuguese economy since ancient times, however, they do reflect the fear of locusts.

Irrespective of the measures taken by each country, the locusts were a common problem -which should be tackled together- since locusts travel freely through the Iberian Peninsula. Similarities in legislative acts, as well as references to each other's outbreaks and researches, seem to support this idea of cooperation. Iberian countries appear to have observed each other's policies and trials. However, reports from Portuguese authorities, as well as descriptions in newspapers, stated that there was a need for cooperation between the Iberian governments to set in motion a common anti-locust programme. Locusts frequently came to Portugal from Spain which rendered inglorious the fight carried out by the Portuguese. Therefore, collaboration was, in this context, considered crucial. 
Historical data on locust pests' occurrences clearly contradicts the assumption that those insects never caused agricultural damages in Portugal. Furthermore, taking into account the pattern revealed by our data (number of districts affected by locust outbreaks per year) which suggest a self-regulation process, control measures taken before the 1940s appear to have been palliative and not truly effective. The 1940s Iberian anti-locust campaigns should, therefore, be taken into account when evaluating Orthoptera populations and designing future management programmes. Insecticides seem, thus, to have had a major impact in diminishing population densities, or at least, to levels that prevent swarms' formation $^{65}$.

Nowadays, no one seems to remember the danger caused once by the Moroccan locust in Portugal. In Spain, although there are still preventive campaigns being conducted, no major surges have been recorded in the last fifty years and locust populations may be diminishing according to the representative organisation of BirdLife International in Spain $^{66}$. Although Dociostaurus maroccanus is classified as Least Concern (LC) in the European Red List of Grasshoppers, Crickets and Bush-crickets, these regional trends in the Iberian Peninsula are alarming. Reasons for outbreaks seeming cease are not obvious and further research is needed. Research shows that the Iberian campaigns of the 1940s marked a turn-over in the anti-locust struggle. Outbreaks have been controlled with localised preventive actions. More effective in their reaction against the surge, they probably led to a decrease in population densities. To clarify differences found, at present time, in the Moroccan locust populations in Portugal and Spain still more historical research is needed for having a better understanding of long-term land use change, as well as having finer data on historic climatic factors. In fact, IUCN considers that climate change and agricultural land use intensification, along with the use of pesticide and fertilizers, are major threats to Orthoptera species in Europe, affecting, consequently reptiles and birds that feed on them (Hochkirch et al., 2016) ${ }^{67}$.

The history of the locust outbreaks might seem an irrelevant subject from the point of view of agricultural losses in current European societies, where the phenomenon has become sporadic and less intense. In fact, although the Iberians have fought the Moroccan locust for centuries, now, it is no longer a major concern for decision-makers, agricultural managers, farmers or the public. However, the present situation in Portugal and Spain hides a history of fruitless struggle, agricultural damages and large expenses, and

65. The same situation is occurring in Spain (see section 5.2).

66. https://www.seo.org/2017/03/22/posible-disminucion-de-poblaciones-de-insectos-enextremadura/ [Late accessed on $27^{\text {th }}$ February 2018].

67. See also LATCHININSKy (1998). 
there is no real evidence that support the mainstream perception that outbreaks have ceased.

Locust outbreaks are an odd subject for urbanites and a "non-there" phenomena for rural communities, which have been progressively forgetting about it. This ecological memory is being erased by a very long sequence of years of numbness. In a biological approach, numbness corresponds to the maintenance of the species in its solitary phase, in the form of dispersed and harmless grasshoppers. In a more cultural approach, numbness recalls people's detachment by ignorance or lack of personal experience.

The risk of locust outbreaks is minimal, someone can argue. A non-action policy -no needs, no measures- was put into practice in Portugal. However, historical accounts clearly suggest that prevention turned out to be a solution. Therefore, to stop prevention, in any circumstance, is not recommended. Risk assessments are currently performed to face invasive species all over the word, namely the Desert locust (Latchininsky \& Sivanpillai, 2010). Regarding the Moroccan locust in the Iberian Peninsula, the potential risk of swarms' formation should still be considered when designing agricultural management and evaluating Orthoptera populations, both in plant pest control measures and in biodiversity conservation programmes (Pina et al., 2017: 27).

What role can be expected of the environmental history of locust outbreaks in this context? Questions on how historical research is useful and used in environmental studies and policies have been continuously raised in the last two decades, at least since the publication of The Uses of Environmental History (Cronon, 1993: 5). Cronon's paper reminds us that our histories are to help change the world, to alert to subjects which are not eminent or urgent, almost non-existent, as the locusts.

Despite difficulties in integrating historical observations in studies on environment or natural sciences, this paper revealed new aspects, or forgotten ones. By assembling a large amount of documentation and depicting it in graphs and maps, a clear picture of the evolution of the acridians' dynamics, in the Iberian Peninsula, throughout time, emerges. Furthermore, the way people dealt with the locust plagues over time is crucial for the understanding of the effectiveness of past measures and to further embark on an effective fight in the future. At the same time this paper gave rise to a set of questions that ecological research, per se, would not, usually, infer: Why is it hard to find Dociostaurus maroccanus in Portugal? Were the Portuguese anti-locust campaigns more effective? Are the Spanish campaigns avoiding migrations to Portugal, leading to a decrease in the Portuguese populations? 
Locusts have the particularity of disappearing (or almost) and [thus] to be forgotten by populations, scientists and decision-makers (Doré \& Barbier, 2015: 192). Although further research is still needed, this paper goes against the trend and as once more highlighted how historical research can illuminate important changes in the structure and function of ecosystems, as well as the ways people have documented, understood, and attempted to manage those changes over time (Alagona et al., 2012). Neglecting the history of locusts in the Iberian Peninsula is a step towards forgetting the presence of the species Dociostaurus maroccanus in the Peninsula, which can lead to the impoverishment of the entomological fauna in fields and natural habitats. Furthermore, abandoning a culture of risk prevention is a dangerous path from oblivion to the possible return of catastrophic surges.

\section{ACKNOWLEDGEMENT}

This work was funded by FCT - the Portuguese Foundation for Science and Technology (UID/HIS/04209/2013, UID/HIS/00286/2013 and IF/00222/2013/CP1166/ CT0001). This paper benefited greatly from a discussion with Sílvia Pina. We also thank to the reviewers of Historia Agraria for their useful comments.

\section{REFERENCES}

Aharoni, I. (1938). On Some Animals Mentioned in the Bible. Osiris, (5), 461-78.

Alagona, P. S., Cooper, S. D., Capelli, M., Stoecker, M. \& Beedle, P. H. (2012). A History of Steelhead and Rainbow Trout (Oncorhynchus mykiss) in the Santa Ynez River Watershed, Santa Barbara County, California. Bulletin of the Southern California Academy of Sciences, 111 (3), 163-222.

Anonymous (1756). Gazeta de Lisboa, 19 (May 13 ${ }^{\text {th }}$ ).

Anonymous (1899). Gafanhotos. O Elvense, 19 (May 14 $\left.4^{\text {th }}\right), 1$.

Anonymous (1900). A praga de gafanhotos. O Elvense, (May $\left.6^{\text {th }}\right), 1$.

Anonymous (1902a). Gafanhotos. Algarve e Alentejo, (March 22 $2^{\text {th }}$ ), 3.

Anonymous (1902b). Gafanhotos. Folha de Beja, (May 8 $\left.{ }^{\text {th }}\right), 1$.

Anonymous (1903). Gafanhotos. Algarve e Alentejo, (February), 1.

Arias, A., Alvez, C., García, F., Martínez de Velasco, D., Olivera, J., Prieto, A. \&

SANTOS, R. (1993). La lucha contra la langosta marroquí (Dociostaurus maroccanus

Thunb.) en Extremadura durante el decenio 1983-1992. Boletín de sanidad vegetal. Plagas, 19 (3), 425-53.

AzcáRATe, I. (1996). Plagas agricolas y forestales en Espana en los siglos XVIII y XIX. Madrid: Ministerio de Agricultura, Pesca y Alimentacion. 
Belayneh,Y.T. (2005). Acridid Pest Management in the Developing World: A Challenge to the Rural Population, a Dilemma to the International Community. Fournal of Orthoptera Research, (14), 187-95.

BuJ, A. (1996). El estado y el control de plagas agrícolas: La lucha contra la langosta en la España contemporánea. Madrid: Ministerio de Agricultura, Pesca y Alimentación.

CAÑizo, J. DEL \& MoReno, V. (1940). Ideas actuales sobre las plagas de langosta. Madrid: Estación de Fitopatología Agrícola.

CAÑIzo, J. DEL (1942). La langosta y el clima. Madrid: Estación de Fitopatología Agrícola.

Chapman, R. F. \& Joern, A. (Eds.) (1990). Biology of Grasshoppers. New York: Wiley.

Cronon, W. (1993). The Uses of Environmental History. Environ History Review, (17), $1-22$.

CuRTis, E. L. (1883). Some Features of Messianic Prophecy Illustrated by the Book of Joel. The Old Testament Student, 3 (4), 97-102.

Deveson, E. D. (2011). The Search for a Solution to Australian Locust Outbreaks: How Developments in Ecology and Government Responses Influenced Scientific Research. Historical Records of Australian Science, 22 (1), 1-31.

Deveson, E. D. \& MartíneZ, A. (2017). Locusts in Southern Settler Societies: Argentine and Australian Experience and Responses, 1880-1940. In E. VAZ, C. J. DE MELO \& L. M. Costa PinTo (Eds.), Environmental History in the Making. 1: Explaining (pp. 259-86). Cham: Springer.

Dirección General de Agricultura, Minas y Montes (1920). La langosta: Lo que es la plaga y modos de combatirla. Hojas divulgadoras, (15-16-17), 1-24.

Dirección General de Agricultura (1933). Plagas del campo: Memoria del Servicio Fitopatológico Agrícola, año 1932. Madrid: Dirección General de Agricultura.

Dirección General de Agricultura (1935). Plagas del campo: Memoria del Servicio Fitopatológico Agrícola, año 1934. Madrid: Dirección General de Agricultura.

Dirección General de Agricultura (1954). Plagas del Campo: Los Servicios de Fitopatología y Plagas del Campo, bosquejo de su actuación en el periodo 1939-49. Madrid: Dirección General de Agricultura.

DORÉ, A. \& BARBIER, M. (2015). Maintenir la vigilance: Les objects-frontières-transationnels dans la pérennisation des dispositifs de surveillance des "soldats de Dieu". Revue d'Anthropologie des connaissances, (9), 189-212.

Freire, D. (2008). A Campanha do Trigo. In A. S. do Paço (Ed.), Os Anos de Salazar (pp. 31-9). Lisboa: Planeta DeAgostini.

Gugliuzzo, E. \& Restifo, G. (2017). Locust Invasions, Climatic Factors and Human Affairs in Modern Age Mediterranean. In E.VAz, C. J. DE Melo \& L. M. Costa Pinto (Eds.), Environmental History in the Making. 1: Explaining (pp. 289-306). Cham: Springer. 
Hochirirch, A., Nieto, A., García Criado, M., Cálix, M., Braud, Y., Buzzetti, F. M., Chobanov, D., Odé, B., Presa, J. J., Willemse, L., Zuna-Kratky, T., Barranco, P., Bushell, M., Clemente, M. E., Correas, J. R., Dusoulier, F., Ferreira, S., Fontana, P., García, M. D., Heller, K. G., Iorgu I. Ș., Ivkovi , S., Kati, V., KleuKers, R., Krištín, A., Lemonnier-Darcemont, M., Lemos, P., Massa, B., Monnerat, C., Papapavlou, K. P., Prunier, F., Pushkar, T., Roesti, C., Rutschmann, F., Irin, D., Skejo, J., Szövényi, G., Tzirkalli, E., Vedenina, V., Barat, J., Barros, F., Cordero, P. J., Defaut, B., Fartmann, T., Gomboc, S., Gutiérrez Rodríguez, J., Holuša, J., Illich, I., Karjalainen, S., Ko ÁRek, P., Korsunovskaya, O., Liana, A., López, H., Morin, D., Olmo-Vidal, J. M., Puskás, G., Savitsky, V., Stalling, T. \& TumbrincK, J. (2016). European Red List of Grasshoppers, Crickets and Bush-Crickets. Luxembourg: Publications Office of the European Union.

INTERnational Institute of Agriculture. BuREAu of Agricultural INTELligence AND Plant Diseases (1916). La lutte contre les sauterelles dans les divers pays. Roma: Institut International d'Agriculture.

KRITSKY, G. (1997). The Insects and Other Arthropods of the Bible, the New Revised Version. American Entomologist, (43), 183-88.

Latchininsky, A. V. (1998). Moroccan Locust Dociostaurus maroccanus (Thunberg, 1815): A Faunistic Rarity or an Important Economic Pest? Fournal of Insect Conservation, (2), 167-78.

LATChInINSKY, A.V. \& SivanPillai, R. (2010). Locust Habitat Monitoring and Risk Assessment Using Remote Sensing and GIS Technologies. In A. Ciancio \& K. G. MukerJI (Eds.), Integrated Management of Arthropod Pests and Insect Borne Diseases (pp. 163-88). Dordrecht: Springer.

Loskutova, M. V. \& Fedotova, A. A. (2015). The Rise of Applied Entomology in the Russian Empire: Governmental, Public, and Academic Responses to Insect Pest Outbreaks from 1840 to 1894. In D. Phillips \& S. Kingsland (Eds.), New Perspectives on the History of Life Sciences and Agriculture (pp. 139-62). Cham: Springer.

MAs, C. (2001). La gestión de la catástrofe: Acción estatal y lucha contra la plaga de langosta en las diócesis de Murcia y Orihuela (1756-1758). Relaciones: Estudios de Historia y Sociedad, 33 (129), 51-86.

Mastbaum, H. (1900). O combate contra os gafanhotos. Archivo Rural, (17), 259-61 Mastbaum H. (1901). Combate dos gafanhotos pela Empusa Acridii. Archivo Rural, (8), 115-17.

Ministério da Agricultura, InsPeCção de PAtologia Vegetal (1919). Instruções para a destruição dos gafanhotos. Lisboa:Tip. Elvense.

Ministerio de Agricultura, Industria, Comercioy Obras Públicas (1901). Memoria de la campaña contra la langosta en 1900-1901. Madrid: Impr. de los Hijos de M. G. Hernández. 
Ministerio de Agricultura, Industria, Comercioy Obras Públicas (1902). Memoria de la campaña contra la langosta en 1901-1902. Madrid: Impr. de los Hijos de M. G. Hernández.

Ministerio de Fomento (1900). Ley de Extinción de la Langosta de 10 de enero de 1879 y reglamento para la ejecución de dicha ley. Madrid: Tipolitografía de Raoult Péant. Ministerio De Fomento (1923). Memoria de la campaña contra la langosta en 19221923. Madrid: Impr. de los Hijos de M. G. Hernández.

Monteiro, J. A. (1900). Instruções indicando os meios praticos de luta contra os gafanhotos. Lisboa: MOPCI-DGA.

Moral, J. DEL (1986). Discusión sobre la situación actual de la plaga de langosta (Dociostaurus maroccanus Thumb.) en Badajoz y resultados de un ensayo de insecticidas para su control. Boletín de Sanidad Vegetal. Plagas, 12 (2), 221-35.

Pais, J. M., Lima, A. M.V. De, Baptista, J. F., Marques de Jesus, M. F. \& Gameiro, M. M. (1976). Elementos para a história do fascismo nos campos: A "campanha do trigo", 1928-38. Análise Social: Revista do Instituto de Ciências Sociais da Universidade de Lisboa, 12 (2), 401-73.

Pestana, J. DA C. (1901). Destruição dos gafanhotos por meio da EMPUSA ACRIDII. Lisboa:Tip. Christovão.

Pesticide Referee Group (PRG) (2014). Evaluation of Field Trials Data on the Efficacy and Selectivity of Insecticides on Locusts and Grasshoppers. Report to FAO. Gammarth, 10-12 December.

Peyrat, E. (2014). Fighting Locusts Together: Pest Control and the Birth of Soviet Development Aid, 1920-1939. Global Environment, (7), 536-71.

Pina, S., Vasconcelos, S., Reino, L., Santana, J., Beja, P., Sánchez-Oliver, J. S., Catry, I., Moreira, F. \& Ferreira, S. (2017). Orthoptera of CastroVerde Special Protection Area (Southern Portugal): New Data and Conservation Value. ZooKeys, (691), 19-48. https://doi.org/10.3897/zookeys.691.14842

Planes, S. (1949). Plagas del Campo. 3rd. ed. Madrid: Ministerio de Agricultura.

RAMÓNY VIDAL, J. (1902). Nueva orientación para extinguir la plaga de la langosta en dos años. Valencia: [s. n.].

RIVAS, F. (1888). Informe oficial sobre la crisis agrícola en las provincias de Ciudad Real, Cuenca, Albacete y Toledo con motivo de la plaga de langosta y juicio crítico de la Ley de Extinción del insecto. In F. Rivas (Ed.), La plaga de la langosta. III: La plaga de la langosta: Sus estragos y medios de combatirla (pp. 41-88). Madrid: Imp. de El Resumen.

SAlido y Estrada, A. (1874). La langosta: Compendio de todo cuanto más notable se ha escrito, sobre la plaga, naturaleza, vida é instintos de este insecto, $y$ de los remedios que se han empleado y ordenado hasta el dia para combatirlo con todas las antiguas y modernas disposiciones dictadas en la materia, para que pueda servir de libro de consulta, 
á todas las corporaciones y autoridades administrativas del pais. Madrid: Impr., Fundición y Estereotipia de Don Juan Aguado.

Schmidt, G. H., Martinho, A. P. \& Paiva, M. R. (2009). The Saltopteran Fauna of Portugal: New Records and Biogeographical Aspects (Orthopteroidea). Fragmenta Entomológica, (41), 15-67.

SEABra, A. (1900). A invasão dos gafanhotos no Algarve. Archivo rural, (3), 35-6.

SERAFIM, T. S. (2017). Seguindo o rasto dos gafanhotos e grilos na Europa. Público, February $27^{\text {th }}$. https://www.publico.pt/2017/02/27/ciencia/noticia/seguindo-o-rasto-dosgafanhotos-e-grilos-na-europa-1763239

SILVA, G. DE M. (1946). A Recente Praga de Gafanhotos. Separata da Revista Agronómica, (IV), 349-64.

SiLVA, V. D. DA (1947). Subsidio para o estudo do Dociostaurus Maroccanus Thumb. em Portugal. PhD Thesis. Lisboa: Instituto Superior de Agronomia.

SisTACH, X. (2007). Bandas, enjambres y devastación: Las plagas de langosta a través de la historia. Córdoba: Almuzara.

SpRENGer, J. (2015). An Ocean of Locusts: The Perception and Control of Insect Pests in Prussian Brandenburg (1700-1850). Environment and History, 21 (4), 513-36.

Uvarov, B. P. (1921). A Revision of the Genus Locusta, L. (= Pachytylus Fieb.), with a New Theory as to the Periodicity and Migrations of Locusts. Bulletin of Entomological Research, 12 (2), 135-63.

Uvarov, B. P. (1928). Locusts and Grasshoppers. London: Imperial Bureau of Entomology.

Vázquez Lesmes, R. \& Santiago, C. (1993). Las plagas de langosta en Córdoba. Córdoba: Publicaciones del Monte de Piedad y Caja de Ahorros.

Waloff, N. \& Popov, G B. (1990). Sir Boris Uvarov (1889-1970): The Father of Acridology. Annual Review of Entomology, 35 (1), 1-26. 